\title{
IMPLEMENTASI STEGANOGRAFI DALAM MENYEMBUNYIKAN PESAN TEKS DENGAN METODE MSB (MOST SIGNIFICANT BIT)
}

\author{
Meri Sri Wahyuni, S.Kom, M.Kom \\ Jurusan Teknik Informatika, Fakultas Teknologi Industri, Institut Teknologi Medan (ITM) \\ JL. Gedung Arca No. 52 Medan \\ meri@itm.ac.id
}

\begin{abstract}
Steganography is the science and art of hiding secret messages (hiding message) such that the presence of (the existence of) the message is not detected by human senses. Steganography using digital media as a place to store that image files and confidential data will be hidden in the form of text. The method used for inserting a message into the image file is a method Most Significant Bit (MSB). This method will replace the first bit of pixel image with the bits penyisip. For inserting a message into a color image, the image and the message must be converted into binary penyisip. Changing the color image into a binary image is used to obtain the values for one image pixel, where one pixel binary image will be replaced with one bit of the eight bits of the character penyisip message. MSB using the technique of Dynamic Cell Spreading (DCS) with copying procedures and processes bitmap buffer to the copy buffer to a bitmap. Procedures copy of the bitmap buffer to be used once in every process and procedure of copying the buffer to be used in the embedding bitmap file. Procedure copied bitmap buffer to aim to change of the form of bitmap which is then converted into assembly language to get the whole bits of the image that has been obtained from the buffer memory.
\end{abstract}

Abstrak - Steganografi adalah ilmu dan seni menyembunyikan pesan rahasia (hiding message) sedemikian sehingga keberadaan (eksistensi) pesan tidak terdeteksi oleh indera manusia. Steganografi ini menggunakan media digital sebagai tempat menyimpan yaitu file citra, dan data rahasia yang akan disembunyikan berupa teks. Metode yang digunakan untuk melakukan penyisipan pesan kedalam file citra adalah metode Most Significant Bit (MSB). Metode ini akan mengganti bit pertama dari piksel citra dengan bit-bit penyisip. Untuk melakukan penyisipan pesan kedalam citra warna, maka citra dan pesan penyisip harus diubah menjadi biner. Pengubahan citra warna menjadi citra biner digunakan untuk mendapatkan satu nilai pada satu piksel citra, dimana satu piksel citra biner akan digantikan dengan satu bit dari delapan bit satu karakter pesan penyisip. MSB menggunakan teknik Dynamic Cell Spreading (DCS) dengan prosedur mengkopi bitmap ke buffer dan proses mengkopi buffer ke bitmap. Prosedur mengkopi dari bitmap ke buffer digunakan sekali di setiap proses dan prosedur mengkopi buffer ke bitmap digunakan pada saat embedding file. Prosedur mengkopi bitmap ke buffer bertujuan untuk merubah dari bentuk bitmap yang kemudian diubah ke bahasa assembly untuk mendapatkan keseluruhan bit dari gambar yang telah didapat dari buffer memori.

Keywords-Kriptoganografi, Msb, Bitmap, Pesan.

\section{PENDAHULUAN}

\section{A. Latar Belakang Masalah}

Steganografi adalah ilmu dan seni menyembunyikan pesan rahasia (hiding message) sehingga keberadaan (eksistensi) pesan tidak terdeteksi oleh indera manusia. Kata steganografi berasal dari bahasa Yunani yang berarti "tulisan tersembunyi" (covered writing). Steganografi digital menggunakan media digital sebagai tempat penampung, misalnya citra, suara, teks, dan video. Data rahasia yang disembunyikan juga dapat berupa citra, suara, teks, atau video. Jika pada kriptografi, data yang telah disandikan (ciphertext) tetap tersedia, maka dengan steganografi ciphertext dapat disembunyikan sehingga pihak ketiga tidak mengetahui keberadaannya.

Metode yang digunakan untuk melakukan penyisipan pesan ke dalam file citra adalah metode
Most Significant Bit (MSB). Metode ini merupakan teknik mengganti bit awal dari piksel citra dengan bitbit penyisip. Untuk melakukan penyisipan pesan ke dalam citra warna, maka citra dan pesan penyisip harus diubah menjadi biner. Pengubahan citra warna menjadi citra biner digunakan untuk mendapatkan satu nilai pada satu piksel citra, dimana satu piksel citra biner akan digantikan dengan satu bit dari delapan bit satu karakter pesan penyisip, teknik tersebut disebut dengan Teknik Dynamic Cell Spreading (DCS).

Dalam tulisan ini teknik akan digunakan adalah steganografi dengan menggunakan Teknik Dynamic Cell Spreading (DCS). Teknik DCS memiliki prosedur utama dalam proses penyembunyian maupun pengembalian ke bentuk awal, yaitu dalam proses mengkopi bitmap ke buffer dan proses mengkopi buffer ke bitmap. Tahap mengkopi dari bitmap ke buffer digunakan sekali di setiap proses dan tahap 
mengkopi buffer ke bitmap digunakan pada saat embedding file. Pada tahapan mengkopi bitmap ke buffer bertujuan untuk merubah dari bentuk bitmap yang kemudian diubah ke bahasa assembly untuk mendapatkan keseluruhan bit dari gambar yang telah didapat dari buffer memori.

\section{B. Perumusan Masalah}

Permasalahan yang dibahas adalah :

1. Bagaimana melakukan penyisipan pesan ke dalam citra warna 24 bit (true color).

2. Bagaimana teknik DCS untuk menyisipkan pesan teks ke dalam gambar menggunakan MSB (Most Significant Bit) dengan teknik penyembunyian pesan Dynamic Cell Spreading.

3. Bagaimana mengekstrak pesan yang tersembunyi dari dalam citra dengan pesan.

\section{Batasan Masalah}

Batasan masalah pada tulisan ini adalah sebagai berikut :

1. Format citra yang digunakan pada penelitian ini adalah format bmp.

2. Metode penyisipan pesan menggunakan Most Significant Bit (MSB).

3. Teks yang digunakan bukan merupakan Ms.Word.

4. Teknik penyembunyian pesan yang digunakan adalah teknik DCS.

\section{LANDASAN TEORI}

\section{A. Steganografi}

Steganografi merupakan ilmu dan seni yang mempelajari cara penyembunyian informasi pada suatu media sedemikian rupa sehingga keberadaannya tidak terdeteksi oleh pihak lain yang tidak berhak atas informasi tersebut. Pengguna pertama (pengirim pesan) dapat mengirim media yang telah disisipi informasi rahasia tersebut melalui jalur komunikasi publik, hingga dapat diterima oleh pengguna kedua (penerima pesan). Penerima pesan dapat mengekstraksi informasi rahasia yang ada di dalamnya. [1]

Penyembunyian data rahasia ke dalam media digital mengubah kualitas media tersebut. Kriteria yang harus diperhatikan dalam penyembunyian data di antaranya adalah:

1. Fidelity. Mutu citra penampung tidak jauh berubah. Setelah penambahan data rahasia, citra hasil steganografi masih terlihat dengan baik. Pengamat tidak mengetahui kalau di dalam citra tersebut terdapat data rahasia.

2. Recovery. Data yang disembunyikan harus dapat diungkapkan kembali (recovery). karena tujuan steganografi adalah data hiding, maka sewaktuwaktu data rahasia di dalam citra penampung harus dapat diambil kembali untuk digunakan lebih lanjut.

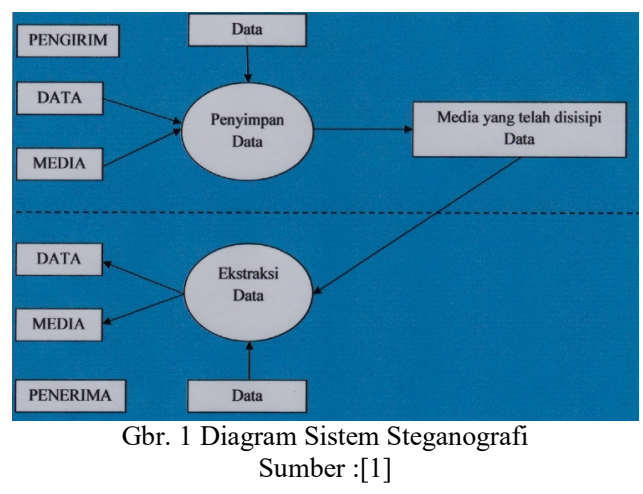

Steganografi digital menggunakan media digital sebagai wadah penampung, misalnya citra, audio, teks, dan video. Sedangkan data rahasia yang disembunyikan dapat berupa berkas apapun. Media yang telah disisipi data disebut stegomessage. Proses penyembunyian data ke dalam media disebut penyisipan (embedding), sedangkan proses sebaliknya disebut ekstraksi. Proses tersebut dapat dilihat pada gambar 2. Penambahan kunci yang bersifat opsional dimaksudkan untuk lebih meningkatkan keamanan.



Gbr. 2 Proses Penyisipan Dan Ekstraksi Dalam Steganografi Sumber :[1]

\section{B. Metode Modifikasi LSB dan MSB}

Sistem Steganografi akan menyembunyikan sejumlah informasi dalam suatu berkas dan akan mengembalikan informasi tersebut kepada pengguna yang berhak. Terdapat dua langkah dalam sistem Steganografi yaitu proses penyembunyian dan recovery data dari berkas penampung. Penyembunyian data dilakukan dengan mengganti bit-bit data di dalam segmen citra dengan bit-bit data rahasia. Metode yang paling sederhana adalah metode modifikasi MSB (Most Significant Bit Modification) dari setiap sample pada audio. Pada susunan bit di dalam sebuah byte (1 byte $=8$ bit), ada bit yang paling berarti (most significant bit atau MSB) dan bit yang paling kurang berarti (least significant bit atau LSB).

Contoh:1 1010010

Bit pada digit pertama merupakan MSB, dan bit pada digit terakhir merupakan LSB. Bit yang cocok untuk diganti adalah bit LSB, sebab perubahan tersebut hanya mengubah nilai byte satu lebih tinggi atau satu lebih rendah dari nilai sebelumnya. Karena perubahan satu-dua buah bit pada beberapa pixel tidak akan terdengar dengan jelas. Metode ini memanfaatkan keterbatasan dari system indera pendengaran manusia yaitu HAS (Human Auditory System). Batas pendengaran manusia berada pada frekuensi antara 20 
$\mathrm{Hz}$ - 20000 Hz. Namun metode ini memiliki keterbatasan jumlah bit pesan yang dapat disisipkan atau disubstitusikan pada setiap byte-nya.

\section{Teknik Dynamic Cell Spreading (DCS)}

DCS merupakan steganografi dengan menggunakan model proteksi terhadap deteksi yang dikembangkan oleh HolgerOhmacht dengan konsep dasar yaitu menyembunyikan file pesan (semua data elektronik) kedalam media gambar. Penyembunyian pesan dilakukan dengan cara menyisipkanya pada bit rendah MSB (Most Significant Bit) dari datapixel yang menyusun file tersebut menggunakan buffer memori sebagai mediapenyimpan sementara. [2].

Dalam proses penggabungan (Stego) antara file gambar dengan teks, untuk file bitmap maka setiap pixel (titik) pada gambar tersebut akan terdiri dari susunan tiga warna merah, hijau, dan biru (RGB) yang masing-masing disusun oleh bilangan 8 bit (byte) dari 0 sampai 255 atau dengan format biner 00000000 sampai 11111111. Dengan demikian pada setiap pixel file bitmap dapat menyisipkan 3 bit data. Contohnya huruf A dapat disisipkan dalam 3 pixel dengan menggunakan metode MSB, misalnya data raster original adalah sebagai berikut :

(00100111 11101001 11001000)

(00100111 11001000 11101001)

(11001000 0010011111101001$)$

Sedangkan representasi biner huruf A adalah 01000001Dengan menyisipkannya pada data pixel diatas maka akan dihasilkan:

$$
\text { (0010011001101001 11001000) }
$$$$
\text { (00100111 1100100011101001) }
$$$$
\text { (11001000 } 0010011101101001)
$$

Terlihat hanya dua bit yang berubah, untuk mata manusia maka tidakakan tampak perubahannya. Secara rata-rata dengan metode ini hanya beberapa data bit yang berubah, sehingga bila dibutuhkan dapat digunakan bitrendah kedua bahkan ketiga.

Proses penggabungan file gambar dengan data elektronik hampir sama tetapi lebih kompleks karna membutuhkan media memori sebagai perantara untuk menghitung jumlah keseluruhan bit yang terdapat didalam file gambar maupun didalam data elektronik yang akan diembedding sehingga memudahkan proses embedding itu sendiri. [2].

\section{METODE PENELITIAN}

Sebelum merancang sebuah sistem, perlu dilakukan analisis terlebih dahulu. Analisis sistem adalah proses menentukan kebutuhan sistem, apa yang harus dilakukan sistem untuk memenuhi kebutuhan klien (user). Dengan adanya analisis sistem, sistem yang dirancang akan lebih baik dan memudahkan pengembang sistem dalam perbaikan apabila pada kemudian hari ditemukan kesalahan atau kekurangan.

\section{A. Metode Steganalisis}

Metode steganalisis yang digunakan merupakan metode steganalisis Enhanced MSB. Seperti telah dijelaskan pada bab sebelumnya, metode ini memanfaatkan kemampuan manusia dalam mengenali objek gambar hasil Enhanced MSB. Metode ini akan mengubah nilai seluruh bit pada suatu byte pixel sesuai dengan nilai bit pertama byte pixel tersebut. Berikut ini algoritma metode steganalisis Enhanced MSB.

1. Periksa bit pertama dari setiap byte data

2. Jika bit pertama bernilai 0 , ubah semua bit pada byte tersebut menjadi 0. Dan jika bit pertama bernilai 1, ubah semua bit pada byte tersebut menjadi 1 .

3. Lihat gambar setelah ada proses perubahan bit untuk menentukan apakah terdapat pesan rahasia atau tidak.

\section{B. Analisa Metode DCS dan MSB}

Penyisipan data teks kedalam data citra bisa dilakukan dengan cara merubah nilai bit pada citra kedalam bentuk biner. Sebagai contoh diambil citra dengan ukuran $3 \times 3$, dengan data teks yang akan disisipkan yaitu ITM.

TABEL I

NILAI BILANGAN DECIMAL PADA CITRA

\begin{tabular}{|c|}
\hline Data Citra \\
\hline 203221192021 \\
\hline 101520211817 \\
\hline 252120191718 \\
\hline 231631212515 \\
\hline 161721 \\
\hline
\end{tabular}

TABEL II

DATA TEKS YANG AKAN DISISIPKAN

\begin{tabular}{|c|c|}
\hline Data Teks & Bilangan Desimal \\
\hline $\mathrm{I}$ & 73 \\
\hline $\mathrm{T}$ & 84 \\
\hline $\mathrm{M}$ & 77 \\
\hline
\end{tabular}

Penyelesaian :

1. Konversi Data Citra Kedalam Biner

Nilai bit citra yang telah didapatkan sebelumnya di konversi kedalam bilangan biner, karena nilai nilai bit yang telah di konversi tersebut nantinya akan digunakan untuk poses penyisipan data teks menggunakan metode MSB. 
TABEL III

HASIL KONVERSI DATA CITRA KEDALAM BINER

\begin{tabular}{|c|c|}
\hline Data Citra & Hasil Konversi \\
\hline 203221 & $00010100,00100000,00010101$ \\
\hline 192021 & $00010011,00010100,00010101$ \\
\hline 101520 & $00001010,00001101,00010100$ \\
\hline 211817 & $00010101,00010010,00010001$ \\
\hline 252120 & $00011001,00010101,00010100$ \\
\hline 191718 & $00010011,00010001,00010010$ \\
\hline 231631 & $00010111,00010000,00011111$ \\
\hline 212515 & $00010101,00011001,00001101$ \\
\hline 161721 & $00010000,00010001,00010101$ \\
\hline
\end{tabular}

2. Konversi Data Teks Kedalam Biner

Setelah bit citra dikonversi, maka data teks juga harus dikonversi kedalam bilangan biner

TABEL III

HASIL KONVERSI DATA CITRA KEDALAM BINER

\begin{tabular}{|c|c|c|}
\hline Teks & Decimal & Hasil Konversi \\
\hline $\mathrm{I}$ & 73 & 01001001 \\
\hline $\mathrm{T}$ & 84 & 01010100 \\
\hline $\mathrm{M}$ & 77 & 01001101 \\
\hline
\end{tabular}

3. Proses Penyisipan Data Teks Pada Citra

Langkah Selanjutnya dilakukan penyisipan pada bit citra. Proses dapat dilihat sebagai berikut :

Data Teks :

$\mathrm{I}=73(01001001)$

$\mathrm{T}=84(01010100)$

$\mathrm{M}=77(01001101)$

Data Citra :

(00010100), (00100000), (00010101)

(00010011), (00010100), (00010101)

(00001010), (00001101), (00010100)

(00010101), (00010010), (00010001)

(00011001), (00010101), (00010100)

(00010011), (00010001), (00010010)

(00010111), (00010000), (00011111)

(00010101), (00011001), (00001101)

(00010000), (00010001), (00010101)

Hasil Penyisipan Data Teks Pada Data Citra (ITM) :

\section{Tindak Lanjut Terhadap Pesan Rahasia}

Setelah terjadi proses steganalisis akan memungkinkan indikasi ada atau tidak terdapatnya sebuah pesan rahasia pada sebuah gambar. Jika terdapat pesan rahasia pada sebuah gambar maka akan dilakukan tindak lanjut pada

gambar dengan melakukan ekstraksi terhadap pesan rahasia sehingga isi pesan dapat diketahui.

\section{Analis Cara Kerja Sistem}

Sistem ini bertujuan untuk menganalisis suatu gambar bitmap sehingga dapat diketahui apakah pada gambar tersebut terdapat pesan rahasia atau tidak. Jika terdapat pesan rahasia maka akan dilakukan ekstraksi pesan untuk mengetahui isi pesan tersebut dan untuk mendapatkan gambar yang terdapat pesan rahasia maka sistem ini dilengkapi dengan fungsi penyisipan pesan (Steganografi).

Sistem akan menerima masukan berupa gambar dalam format bitmap. Untuk proses penyisipan pesan, pesan yang telah ditentukan akan disisipkan ke dalam gambar dengan metode penyisipan pesan MSB dan sistem akan memberikan keluaran berupa gambar yang telah disisipi pesan. Parameter dalam analisis ini antara lain yang pertama perubahan bit sebelum dan setelah dilakukan penyisipan pesan dan perubahan bit setelah dilakukan analisis. Parameter kedua antara lain kapasitas citra sebelum dan setelah dilakukan penyisipan pesan ke dalam gambar. Kemudian untuk proses steganalisis, gambar akan dianalisis dengan metode steganalisis Enhanced MSB. Lalu sistem akan memberikan keluaran berupa gambar hasil Enhanced MSB. Jika pada gambar terdeteksi pesan rahasia, maka dapat diambil tindak lanjut dengan melakukan ekstraksi pesan rahasia.

\section{E. Perancangan Sistem}

Perancangan sistem ini akan dijelaskan dengan menggunakan Flowchart, UML dan perancangan antarmuka sistem.

\section{F. Gambaran Umum Sistem}

Gambaran umum alur kerja sistem akan digambarkan dalam bentuk Flowchart, yaitu pada gambar 3.

$(00010100)(10100000)(00010101)$
$(00010011)(10010100)(00010101)$
$(00001010)(10001101)(00010100)$
$(10010101)(00010010)(10010001)$
$(00011001)(10010101)(00010100)$
$(00010011)(00010001)(10010010)$
$(00010111)(00010000)(10011111)$
$(10010101)(00011001)(10001101)$
$(00010000)(00010001)(00010101)$

Inilah hasil penyisipan data teks kedalam citra. Bisa dilihat perubahan nilai bit pada citra setelah dilakukan penyisipan data teks. 


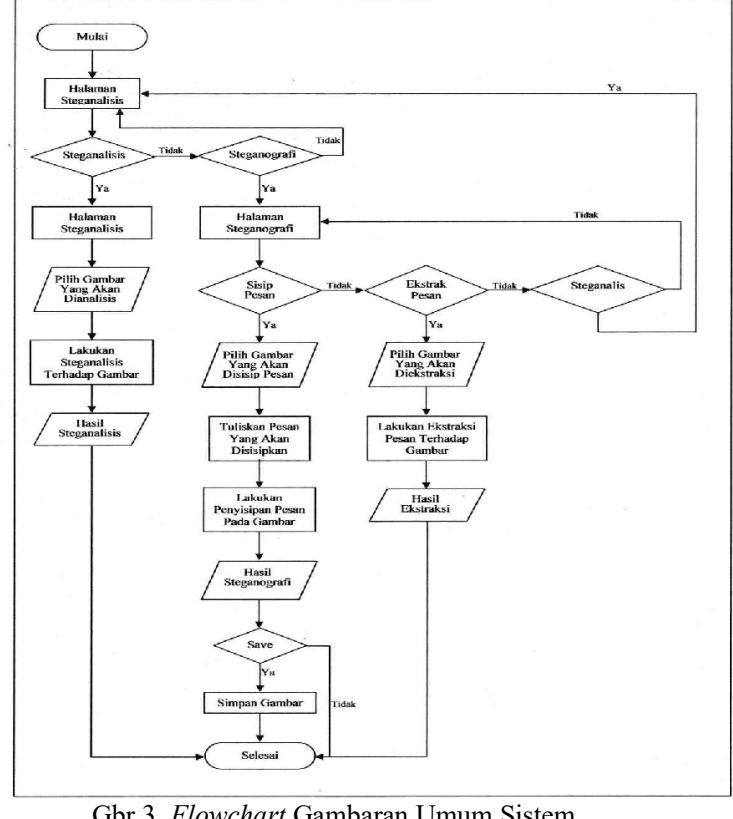

Gbr 3. Flowchart Gambaran Umum Sistem

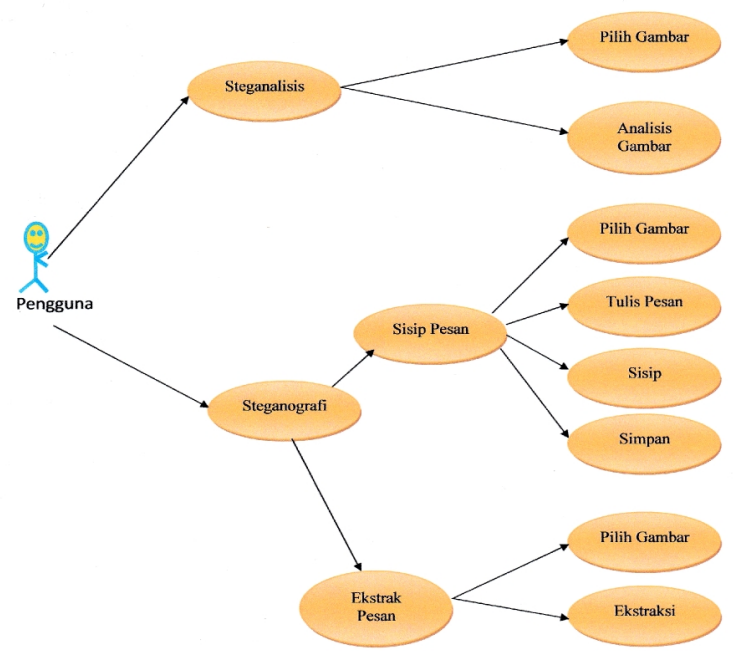

Gbr 4. Use Case Aplikasi Steganalisis

\section{G. Use Case Diagram}

Fungsionalitas sistem digambarkan dalam bentuk Use Case Diagram. Sementara Activity Diagram menggambarkan alur aktivitas sistem. Berikut ini Use Case Diagram dari aplikasi steganalisis. Lihat pada gambar 4.

Spesifikasi untuk masing-masing Use Case adalah sebagai berikut.

1. Use Case Steganalisis.

2. Use Case Pilih Gambar (menu Steganalisis).

3. Use Case Analysis.

4. Use Case Steganografi.

5. Use Case Sisip Pesan.

6. Use Case Pilih Gambar (menu Sisip Pesan).

7. Use Case Tulis Pesan.

8. Use Case Sisip.

9. Use Case Simpan.

10. Use Case Ekstrak Pesan.
11. Use Case Pilih Gambar (menu Ekstrak Pesan).

12. Use Case Ekstraksi.

\section{H. Perancangan Antarmuka Sistem}

Antarmuka pemakai (User Interface) merupakan bagian dari perangkat lunak (software) yang menyediakan sarana untuk pemakai agar bisa berkomunikasi dengan sistem atau terjadinya dialog antara program dengan pemakai program. Berikut ini adalah rancangan antarmuka aplikasi steganalisis yang akan dibangun.

1. Halaman Login Aplikasi.

Halaman Login Merupakan tampilan untuk pengamanan sebelum masuk kedalam halaman utama aplikasi steganografi.

2. Halaman Utama Aplikasi.

Halaman utama aplikasi menampilkan tampilan awal aplikasi. Terdapat sebuah tombol yaitu begin yang berfungsi untuk masuk ke halaman steganalisis dan steganografi.

3. Halaman Steganalisis Aplikasi.

Halaman Steganalisis dapat diakses oleh pengguna dengan memilih menu Steganalisis pada menubar.

4. Halaman Steganografi Aplikasi.

Halaman Steganografi dapat diakses oleh pengguna dengan memilih menu Steganografi pada menubar. Tampilan halaman steganografi ini merupakan tampilan halaman Sisip Pesan. Pada halaman ini terdapat 4 buah menu, yaitu Menu Utama, Steganalisis, Sisip Pesan dan Ekstrak Pesan.

5. Halaman Ekstrak Pesan

Halaman Ekstrak Pesan dapat diakses oleh pengguna dengan memilih menu Ekstrak Pesan pada menubar. Pada halaman Ekstraksi Pesan terdapat tombol Pilih Gambar dan Ekstraksi. Pengguna akan memilih gambar terlebih dahulu melalui tombol Pilih Gambar. Gambar yang telah dipilih oleh pengguna akan ditampilkan pada picture box di bawah tombol Pilih Gambar. Kemudian, melalui tombol Ekstraksi, gambar yang telah dipilih akan mengalami proses ekstraksi, dan pesan tersembunyi hasil ekstraksi akan ditampilkan pada text box di sebelah kanan tombol Pilih Gambar.

\section{IV.HASIL DAN PEMBAHASAN}

\section{A. Implementasi}

Adapun implementasi dari program ini terdiri dari 3 bagian, yaitu:

1. Proses untuk menyisipkan informasi pesan teks ke dalam sebuah gambar.

2. Proses untuk menganalisis ada atau tidaknya terdapat sebuah pesan rahasia pada suatu gambar.

3. Proses untuk melihat pesan teks yang sudah disisipkan sebelumnya.

\section{B. Tampilan Penggunaan Aplikasi}

Tampilan halaman aplikasi steganalis dapat dilihat dalam gambar-gambar tampilan penggunaan aplikasi 
berikut yang merupakan hasil analisis dan perancangan sistem.

\section{Halaman Login}

Halaman Login Merupakan tampilan untuk pengamanan sebelum masuk kedalam halaman utama aplikasi steganografi.

\section{Halaman Depan Aplikasi}

Halaman utama aplikasi merupakan tampilan awal ketika steganalisis dijalankan. Pada halaman ini terdapat informasi mengenai aplikasi dan pembuat aplikasi.

\section{E. Halaman steganalisis}

Dalam mengakses halaman steganalisis, pengguna hanya perlu memilih menu Steganalisis pada menubar aplikasi. Pada halaman steganalisis, terdapat dua buah tombol, yaitu tombol Pilih Gambar untuk memilih gambar yang diinginkan, dan tombol Analisis untuk mengeksekusi proses steganalisis terhadap gambar. Gambar yang dipilih oleh pengguna melalui tombol Pilih Gambar akan ditampilkan pada scrollpane Gambar Awal. Begitu juga dengan gambar hasil steganalisis akan ditampilkan pada scrollpane Gambar Hasil Steganalisis dan terdapat dua tombol lagi yaitu tombol nilai piksel awal dan nilai piksel hasil. Nilai piksel awal ini berfungsi untuk menggetahui bit-bit yang terdapat pada gambar sebelum dilakukan proses analisis. Nilai piksel akhir untuk mengetahui bit-bit pada sebuah gambar setelah dilakukan analisis, dengan adanya tombol ini pengguna dapat mengetahui perubahan-perubahan bit-bit yang terdapat dalam sebuah gambar.

\section{F. Halaman Steganografi}

Dalam mengakses halaman steganografi, pengguna memilih menu Steganografi pada menubar aplikasi. Pada halaman steganografi, terdapat tiga buah tombol, yaitu tombol Pilih Gambar untuk memilih gambar yang diinginkan, tombol Sisip untuk mengeksekusi proses penyisipan pesan ke dalam gambar dan tombol simpan untuk menyimpan hasil penyisipan. Juga terdapat dua buah textarea yang digunakan untuk menuliskan pesan yang ingin disisipkan dan tempat penyimpanan setelah dilakukan proses penyisipan. Gambar yang dipilih oleh pengguna melalui tombol Pilih Gambar akan ditampilkan pada scrollpane Gambar Awal. Sementara gambar hasil steganografi akan ditampilkan pada scrollpane Gambar dengan Pesan Tersembunyi. Berikut ini adalah gambar tampilan halaman steganografi.

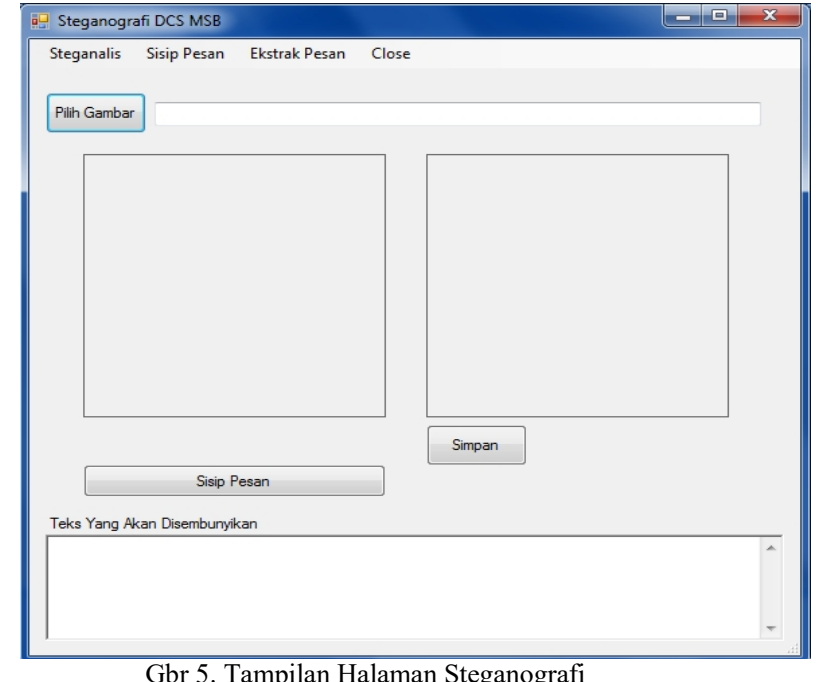

\section{G. Halaman Ekstraksi Pesan}

Untuk dapat mengakses halaman ekstraksi pesan, pengguna hanya perlu memilih menu Ekstraksi Pesan pada menubar aplikasi. Pada halaman ekstraksi pesan, terdapat dua buah tombol, yaitu tombol Pilih Gambar untuk memilih gambar yang diinginkan, dan tombol Ekstraksi untuk mengeksekusi proses ekstraksi pesan terhadap gambar. Gambar yang dipilih oleh pengguna melalui tombol Pilih Gambar akan ditampilkan pada scrollpane Gambar Awal. Berikut ini adalah gambar tampilan halaman ekstraksi pesan

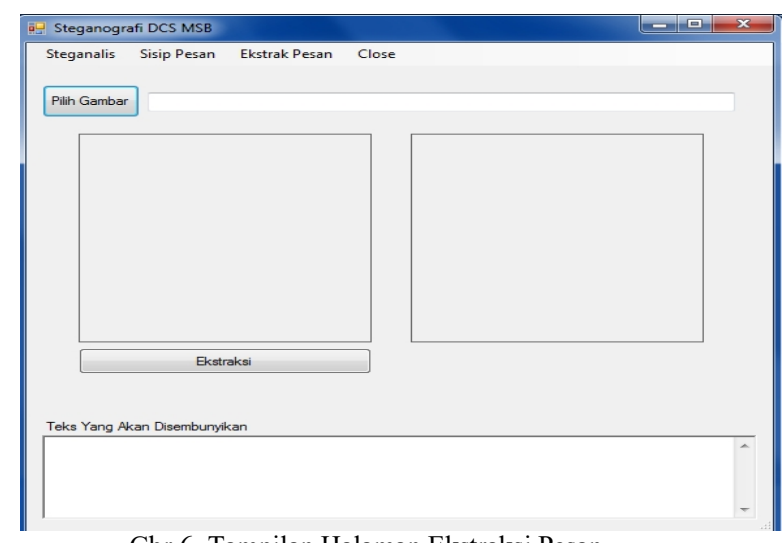

Gbr 6. Tampilan Halaman Ekstraksi Pesan

\section{H. Pengujian Sistem}

Tujuan dilakukan pengujian sistem adalah untuk memastikan bahwa semua kebutuhan perangkat lunak telah berhasil diimplementasikan dengan baik. Pengujian sistem dilakukan dengan melakukan uji coba terhadap fungsi sistem yang telah dibangun. Berikut ini pengujian sistem berdasarkan proses penyisipan pesan, proses steganalisis dan proses ekstraksi pesan.

\section{Proses Steganografi}

Pengujian sistem pada proses steganografi mengacu pada metode penyisipan pesan MSB. Pengujian sistem untuk proses steganografi akan dimulai dari dipilihnya halaman Steganografi pada menubar sampai pesan 
rahasia berhasil disisipkan dan gambar yang mengandung pesan rahasia ditampilkan.

\section{J. Halaman Steganografi}

Pengguna mengakses halaman Steganografi untuk dapat melakukan penyisipan pesan ke dalam gambar. Tampilan halaman steganografi dapat dilihat pada Gambar 7.

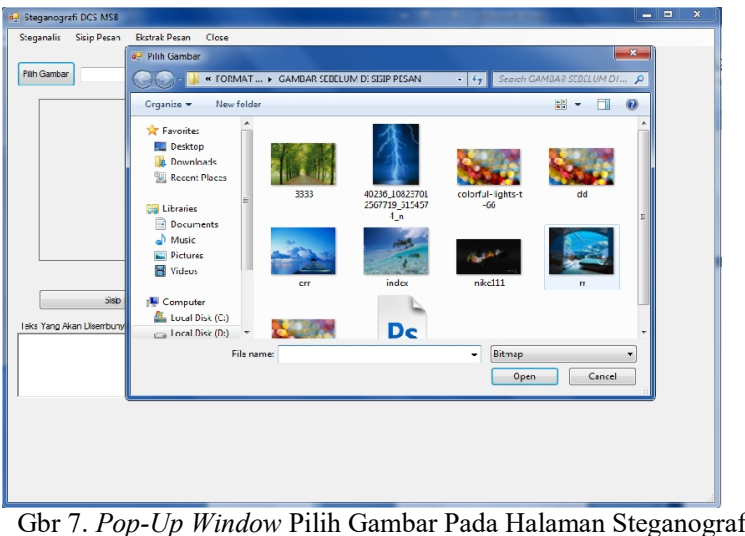

\section{K. Pilih Gambar}

Gambar yang akan disisipi pesan dapat dipilih melalui tombol Pilih Gambar. Saat tombol Pilih Gambar dieksekusi, maka akan muncul pop-up window untuk mengakses lokasi gambar disimpan. Kemudian gambar yang telah ditentukan akan ditampilkan pada scrollpane Gambar Awal. Dan lokasi tempat penyimpanan gambar tersebut juga akan ditampilkan.

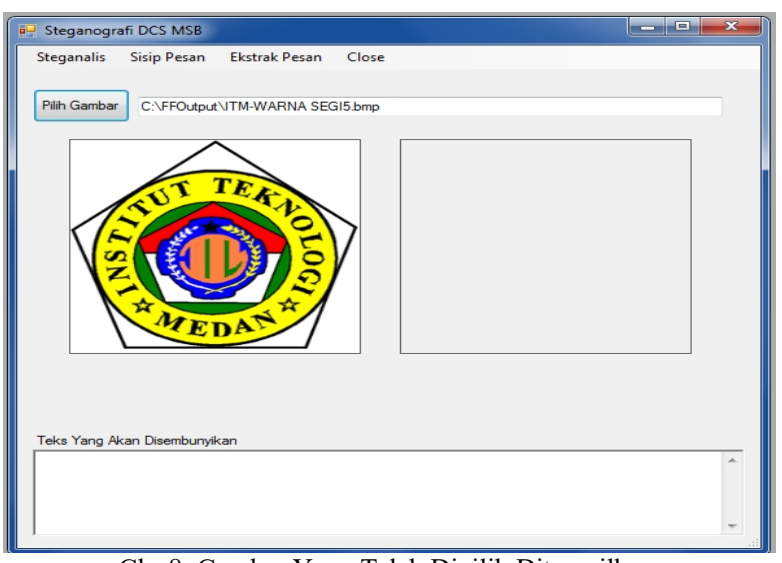

Gbr 8. Gambar Yang Telah Dipilih Ditampilkan

\section{KESIMPULAN DAN SARAN}

\section{A. Kesimpulan}

Berdasarkan hasil penelitian dalam penyusunan skripsi ini maka dibuat suatu kesimpulan, yaitu :

1. Penggunaan Steganografi untuk menyisipkan pesan dapat dilakukan dengan menggunakan metode Most Significant Bit (MSB) dengan metode teknik Dynamic Cell Spreading (DCS).

2. Citra bitmap dapat menerima penyisipan pesan namun bila terjadi perubahan pada citra maka pesan tersebut akan hilang.
3. Perancangan dalam aplikasi ini dapat dilakukan dengan menggunakan metode Most Significant Bit (MSB) namun hasil gambar yang telah di sisipkan pesan akan sedikit berbeda dengan gambar sebelum nya.

\section{B. Saran}

Adapun saran-saran yang diusulkan untuk kesempurnaan skripsi ini adalah:

1. Perancangan aplikasi yang dibangun masih banyak kekurangan dan kelemahan oleh karena itu agar para pembaca dan peneliti dapat memperbaiki dan menyempurnakannya.

2. Agar para pengguna dapat menggunakan aplikasi yang dirancang untuk dapat mengetahui teknik steganografi.

3. Disarankan agar menggunakan format citra lain sebagai objek penerima pesan menggunakan metode MSB dan teknik DCS.

\section{REFERENCE}

[1] Dony Arius, 2009. Keamanan Multimedia, Penerbit Andi. Yogyakarta.

[2] Ermadi Satria Wijaya, Yudi Prayudi, 2004. Media Informatika, Vol. 2. Yogyakarta 